\title{
Radiographic analysis and performance of coffee seeds ${ }^{1}$
}

\author{
Heiber Andres Trujillo ${ }^{2 *}\left(\mathbb{D}\right.$, Francisco Guilhien Gomes-Junior ${ }^{3}$ (D), \\ Idemauro Antonio Rodrigues de Lara ${ }^{4}$ (D), Silvio Moure Cicero ${ }^{3}$ (iD
}

\begin{abstract}
Radiographic analysis has been efficient in identifying the main changes in the internal morphology of seeds, being increasingly used in quality control programs due to their practicality, objectivity and speed in obtaining the results. Despite these advantages, there are still no studies proving the efficiency of these techniques for coffee seed analysis. Thereby, the aim of this research was to evaluate the internal morphology of coffee seeds (Coffea arabica L.) through the analysis of radiographic images and their relation with germination performance. Radiographic images of seeds of the cultivars Bourbon and Catucaí 20/15, each represented by six lots, were examined and the seeds were seeded and seedling emergence, shoot length, stem diameter and shoot dry mass were evaluated. Seeds of Bourbon presented high percentage of intact seeds, as well as better performance in the germination of the lots compared to Catucaí 20/15, which presented more incidence of damaged seeds and lower germination. The radiographic images allowed identifying seeds with malformations, tissue deterioration and damage caused by the coffee borer. This non-destructive imaging technique is efficient in identifying intact seeds, with potential to germinate and produce vigorus seedlings.
\end{abstract}

Index terms: Coffea arabica L., X-ray, digital images, germination performance.

\section{Análise radiográfica e desempenho de sementes de café}

\begin{abstract}
RESUMO - A análise radiográfica tem sido eficiente na identificação das principais alterações na morfologia interna de sementes, sendo cada vez mais utilizada em programas de controle de qualidade, devido à sua praticidade, objetividade e rapidez na obtenção dos resultados. Apesar dessas vantagens, ainda não existem estudos que comprovem a eficiência dessas técnicas na análise de sementes de café. Assim, o objetivo desta pesquisa foi avaliar a morfologia interna de sementes de café (Coffea arabica L.) através da análise de imagens radiográficas e sua relação com o desempenho germinativo. Foram avaliadas imagens radiográficas de sementes das cultivares Bourbon e Catucaí 20/15, cada uma representada por seis lotes. As sementes foram semeadas e avaliada a emergência de plântulas, comprimento da parte aérea, diâmetro do caule e massa seca da parte aérea. As sementes de Bourbon apresentaram alta porcentagem de sementes intactas, bem como melhor desempenho na germinação dos lotes em relação ao Catucaí 20/15, que apresentou maior incidência de sementes danificadas e menor germinação. As imagens radiográficas permitiram identificar sementes com malformações, deterioração de tecidos e danos causados pela broca do café. Esta técnica de imagens não destrutiva é eficiente na identificação de sementes intactas, com potencial para germinar e produzir plântulas vigorosas.
\end{abstract}

Termos para indexação: Coffea arabica L., raios X, imagens digitais, desempenho germinativo.

\section{Introduction}

The coffee belongs to the family Rubiaceae and to the genus Coffea, which is represented by about 70 species, involving Coffea arabica L. In the nearly 80 tropical and

${ }^{1}$ Submitted on: 3/26/2019. Accepted for publication on: 9/19/2019.

${ }^{2}$ Department of Field Crops, Faculty of Agriculture, Ondokuz Mayıs University - Samsun, Turkey. subtropical countries where coffee is grown, coffee represents great economic importance (Silva et al., 1999; Clay, 2004). The installation of most commercial coffee plantations is carried out by seedlings obtained from seeds. Often coffee seeds present problems related to changes in internal morphology,

${ }^{3}$ Departamento de Produção Vegetal, USP/ESALQ - Piracicaba, SP, Brasil. ${ }^{4}$ Departmento de Ciências Exatas, USP/ESALQ - Piracicaba, SP, Brasil. ${ }^{5}$ Corresponding author $<$ hatrujillos@usp.br $>$ 
such as the occurrence of malformations, damage caused by tissue deterioration and injuries caused by the coffee borer, which can reflect in loss to the physiological potential.

On the appearance of malformed seeds, although they are not fully clarified as to the reasons for the occurrence, it is believed that this is determined by the genotype (cultivar) and its interaction with the environment (Mendes and Bacchi, 1940; Goulart et al., 2007). Changes related to tissue deterioration mainly correspond to the interaction of the seeds with the environmental conditions and the processes in which they are submitted. Factors such as high relative humidity of the air favor the incidence of pathogens, mainly fungi, which cause the deterioration of the tissues (Rosa et al., 2005). During the formation of the fruits and seeds can also occur the attack of the coffee borer (Hypothenemus hampei Ferrari, 1867) (Coleoptera: Curculionidae: Scolytinae) which, when it does not cause the fruit to fall, reduces the density of the seeds. The insect female pierces the fruit and deposits its eggs in a gallery built on the endosperm of the seed; both larvae and adults cause damage to fruits and seeds (Damon, 2000).

These factors lead to a considerable increase in the period for the formation of seedlings and difficulties in establishing the culture in the field (Sguarezi et al., 2001; Eira et al., 2006). The intensity of occurrence and interference of these problems varies according to the species, the cultivar, the production conditions, the harvesting method and the process used to extract the seeds (Giomo et al., 2008).

One of the basic requirements for identifying problems associated with the physiological potential of seeds is the investigation of their internal morphology (Gomes-Junior, 2010). Researches with seeds of paprika (Dell'Aquila, 2007), papaya (Santos et al., 2009) and eggplant (Silva et al., 2012) showed a relationship between the occurrence of malformed seeds and loss of germination. Currently, techniques of image analysis are being increasingly used to evaluate the internal morphology of seeds. Radiographic analysis, for example, is a non-destructive method used for this purpose, which, in a few seconds, makes it possible to identify the main alterations caused by different factors. This method is advantageous because it does not compromise the viability of the seeds due to the low radiation dose used, allowing other tests with the same samples (Bino et al., 1993; ISTA, 1995),

\footnotetext{
${ }^{1}$ The normal fruit of arabica coffee has a bilocular ovary with only one ovule in each locule. Each ovule gives rise to a seed, and during the development of the fruit, the pressure that one seed exerts on the other causes each one to have a flat-convex shape.

${ }^{2}$ When one of the ovules atrophies, the entire space of the ovarian cavity is filled by a single seed that, in the absence of pressure from the other seed, becomes oval.
}

in order to establish cause and effect relationships. Thus, the use of radiographic analysis to evaluate the internal morphology of coffee seeds can help to select the best seeds to ensure efficiency in the seedling production process. The aim of this research was to evaluate the internal morphology of coffee seeds (Coffea arabica L.), by means of the analysis of radiographic images, and its relation with the germinative performance.

\section{Material and Methods}

The research was carried out at the laboratories of seed analysis and image analysis of the department of crop science at the Escola Superior de Agricultura Luiz de Queiroz, Universidade de São Paulo (USP/Esalq), Piracicaba, SP, Brazil. Coffee (Coffea arabica L.) seeds of the cultivars Bourbon and Catucai 20/15, represented by six lots from the same harvest year, were previously selected. The evaluation of the internal morphology of the seeds through the radiographic analysis was performed aiming to identify malformations, deteriorated inner tissues and injuries caused by coffee borer. This evaluation was performed for each seed lot and cultivar.

$X$-ray test: 100 seeds without parchment were radiographed from each lot, positioned at $28.6 \mathrm{~cm}$ from the X-ray emission source, using a Faxitron X-Ray digital equipment, model MX-20 DC-12, coupled to a Core 2 Duo (3.16 GHz, 3 GB RAM, 160 GB HD) and MultiSync monitor (17-inch 1990SX LCD). The seeds were fixed in groups of 20 on a sheet of clear acetate $(210 \times$ $297 \mathrm{~mm}$ ), using double-sided adhesive tape. After the X-rays, the images were saved in JPEG format (Joint Photographics Experts Group). Based on the interpretation of the radiographic images, the percentage of occurrence of intact, malformed, presenting deteriorated tissues and seeds attacked by the coffee borer were calculated for each lot and cultivar. The intact seeds were considered complete and well developed, without damage caused by mechanical action or insects, being identified as flat ${ }^{1}$, moca $^{2}$, concha ${ }^{3}$ and triangular ${ }^{4}$, according to the classification used by Giomo et al. (2008), respectively presented by Figures 1B, 1C, $1 \mathrm{D}$ and $1 \mathrm{E}$. The seedling emergence test was performed with the seeds classified by the X-ray test and the seedling performance results were compared with the radiographic images.

Emergence of seedlings: the radiographed seeds were seeded in sand in plastic boxes $(32 \mathrm{~cm} \times 28 \mathrm{~cm} \times 10 \mathrm{~cm})$

\footnotetext{
${ }^{3}$ The simultaneous development of two or more distinct ovules in a single locus gives rise to two or more seeds, whose endosperm develops juxtaposed and imbricated in the same locus and surrounded by a single endocarp.

${ }^{4}$ Tri or plurilocular ovaries in which the ovules normally develop give rise to three or more independent seeds, one in each locule, which take the approximate shape of a spherical spindle.
} 
containing perforations at the bottom to allow drainage. The seeds were distributed in a way that could be identified according to the radiographic analysis, on a layer of $5 \mathrm{~cm}$ of sand and covered with a layer of $1 \mathrm{~cm}$. The sand was moistened with an amount of water equivalent to $60 \%$ of the retention capacity and the boxes kept in an uncontrolled environment. The temperature and relative humidity conditions were monitored by means of thermohygograph records (Novus brand, Log Box-RHT-LCD model). Seedling evaluation was performed by counting the number of seedlings emerged for each seed lot and cultivar until stabilization up to 70 days after seeding. Seedlings with cotyledonary leaves enveloped by the endosperm (cotyledonary leaves not expanded) in the phosphorus stick were considered, according to Ascanio (1994). The results were expressed as mean percentage of seedlings emerged for each lot.

Emergence speed index: it was determined together with the seedling emergence test, the counting being performed every three days, until the emergence was stabilized. For the determination of the rate of emergence speed index was used the equation proposed by Maguire (1962):

$$
\mathrm{ESI}=\mathrm{N} 1 / \mathrm{D} 1+\mathrm{N} 2 / \mathrm{D} 2+\ldots+\mathrm{Nn} / \mathrm{Dn} .
$$

At where: ESI = emergence speed index; N1, N2, ..., $\mathrm{Nn}=$ number of normal seedlings in the first, second to last count, respectively and D1, D2, ..., Dn = number of days from the first, second, to the last count, respectively.

Shoot length, stem diameter and shoot dry matter mass: evaluations were carried out 120 days after sowing of the radiographed seeds. The shoot length of the plants was determined measuring the stem from the substrate surface until the last pair of leaves were inserted using a ruler graduated in millimeters and the results were expressed in centimeters. The diameter of the stem was determined $2 \mathrm{~cm}$ below the insertion point of cotyledonary leaves using digital caliper, with results expressed in $\mathrm{mm}$. The shoot dry matter mass was determined in an oven at $70{ }^{\circ} \mathrm{C}$ for 72 hours, according to Favarin et al. (2003); for that, the shoot of each plant was placed individually in paper bags and the weighing was carried out using a digital scale with precision of three decimal places $(0.001 \mathrm{~g})$, with results expressed in milligrams per plant. The mean values of shoot length, stem diameter and shoot dry matter mass were obtained by dividing the values corresponding to the sum of the data of each parameter by the total number of seeds. The results of the seedling performance were synthesized in the analysis of variance and then associated with the seed classification obtained in the X-ray test.

Statistical procedure: the response variable considered is the seed classification, which is measured in different categories
(1: intact seed, 2: malformed seed, 3: deteriorated seed and 4: injuries by the coffee borer). To relate the radiographic analysis to the effects of cultivar and lot was used the proportional odds' regression model, which is a multivariate extension of Generalized Linear Models (McCullagh, 1980). Such model allows to estimate the probabilities associated with each of the response categories.

The analysis of the seedling emergence of X-rayed seeds was done using the multiple logistic regression model (Agresti, 2012). The quality of fit of the model was evaluated using the deviation function and the quantile-quantile graph with simulated envelopes, considering a level of $95 \%$ and for the selection of models, the likelihood ratio test was used.

For the analysis of the quantitative of seedling performance, the methodology of the general linear models was used, synthesized in the analysis of the variance by means of the statistical model associated to the experimental design with subdivided plots scheme. The level of significance adopted in the analyzes was $5 \%$ and it was processed using software R (R Core Team, 2018).

\section{Results and Discussion}

The main morphological variation observed between seeds of the two cultivars corresponded to the size; regardless of lot, the seeds of Bourbon were larger than those of the Catucaí 20/15 (Figure 1A), manifesting itself as a characteristic of each cultivar. According to Aguiar et al. (2004), the size of coffee seeds may also vary according to the place of cultivation, climatic conditions and management during the productive cycle. As it can be observed in Figures 1B, 1C, $1 \mathrm{D}$ and $1 \mathrm{E}$, the category of intact seeds was composed of different types, namely flat seed, moca, concha and triangular, according to Giomo et al. (2008). The seeds of this category were easily identified during the interpretation of radiographic images, as they showed no dark gray spots (characteristic of malformed seeds or presence of deteriorated tissues), as well as the absence of galleries that are typical signs of the injuries caused by coffee borer (Figures 1F, 1G, 1H and 1I). In the $\mathrm{X}$-ray identification of malformed seeds, no relationship was found between the size and the occurrence of seeds with this type of problem; the typical characterization was the partial formation of the endosperm in the central region of the seed, as it can be observed in Figure 1F. According to Goulart et al. (2007), factors such as genotype, environmental conditions during fruit management and development, fruit position in the mother plant and harvesting season may lead to the appearance of unfertilized or empty locus which lead to the production of malformed seeds. The variations presented in 
the seeds of each cultivar suggest that these occurred due to the environmental characteristics in which the seeds were exposed during the production stages.

Regarding the data analysis, variations in the occurrence of intact seeds with malformations, deteriorated tissues and seeds attacked by the coffee borer were observed among the cultivars. From the exploratory data analysis in the statistical model, a higher proportion of seeds classified as intact was found, 93.66\% in Bourbon and 90.16\% in Catucaí 20/15 (Figure 2). Regarding the alterations, the highest proportions were observed for deteriorated seeds, followed by seeds with injuries by the coffee borer and, to a lesser extent, malformed seeds in the two cultivars $(4.16 \%, 0.66 \%, 1.50 \%$ for Bourbon and 5.33\%, 3.66\% and $0.83 \%$ for Catucai 20/15, respectively). The adjustment of proportional odds' models, from the simplest to the most complete, and the analysis of the likelihood ratio showed that there were no effects of the cultivar $\times$ lot interaction $(p=0.1301)$ and $\operatorname{lot}(p=0.2841)$. In view of the object of the study, the lot of effect was maintained in the model. Using the selected model, with additive lot and cultivar effect, the proportions (prediction of the model) were obtained, according to Table 1.

It is observed that the predicted values of intact seeds, considering lot and cultivar effects are close to $90 \%$ or higher, corroborating the values observed in the descriptive analysis and signaling good predictive capacity of the model used. In
Table 1, the lots followed by the same letter do not differ in relation to the estimated proportions, there was homogeneity in the distribution of the internal characteristics of the lots of seeds in Bourbon and Catucaí 20/15, but not among the cultivars. Thus, the radiographic analysis allowed to estimate the proportions of the main changes in the internal morphology of the seeds endosperm, allowing to study the possible effects of these changes on the germinate performance of the seed lots. In practice, the methods evidenced that the evaluation system by radiographic images had accuracy in the selection of seeds free from changes in their internal morphology for each cultivar.

Regarding the germination and seedling emergence analysis, an exploratory lot and cultivar study was initially carried out, where the effects of internal seed changes on germination performance were verified, as shown in Figure 2. The seeds identified with the D notation inside the square of red or green color represent, respectively, seeds with deteriorated tissues that did not germinate or which gave rise to normal seedlings. This same logic applies to intact seeds (I), malformed seeds (M) and seeds with injuries caused by the coffee borer (B). Also, for Bourbon, by the analysis of Figure 2, it can be observed that some intact seeds did not germinate and the number of seeds with this behavior varied between lots. In lot 5 , for example, $17 \%$ of the intact seeds did not germinate, whereas for lots 4 and 6 this ratio was only 5.3 and $6.4 \%$, respectively. For Catucaí 20/15, some intact seeds did not germinate and the number of seeds

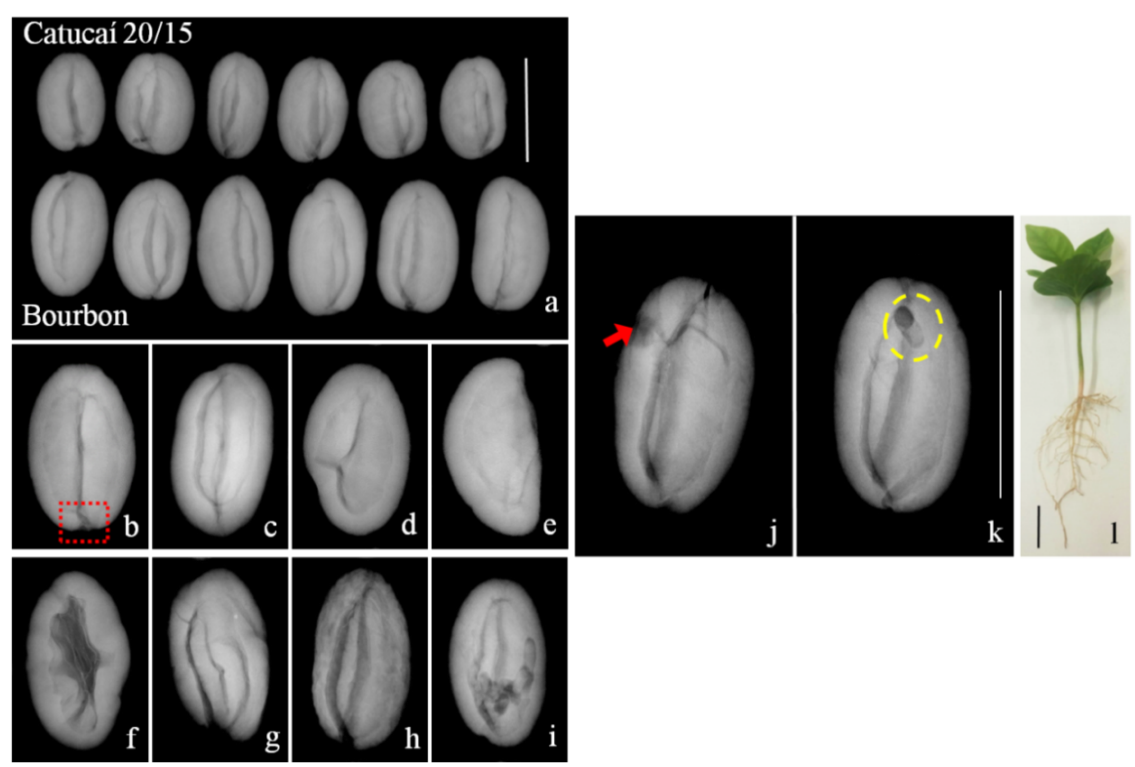

Figure 1. Radiographic images of seeds of cultivars Catucaí 20/15 and Bourbon, (a) and examples of intact seeds (two cultivars) of flat type (b), moca (c), concha (d) and triangular (e) of malformed seeds ( $\mathrm{f}, \mathrm{g}$ ), of seed with deteriorated tissues (h) and seed with injuries caused by the coffee borer (i). Radiographic images of coffee seeds of the cultivar Catucaí 20/15 presented deteriorated tissues (j) and injuries caused by the coffee borer $(\mathrm{k})$ that originated normal seedlings (1). The red rectangle delimits the region of the embryonic axis (b). The bars correspond to $1 \mathrm{~cm}$. 
with this behavior varied between lots. It was observed that all the malformed seeds did not germinate, seeds with deteriorated tissues almost always did not germinate and, in some cases, seeds with injuries caused by the coffee borer originated normal seedlings as shown in Figure 2. These results confirm Van der
Burg et al. (1994) statement on radiographic analysis and its property in exclusively evaluating physical attributes of seeds.

By adjusting the logistic regression model, we verified the association of the factors (lot, cultivar and classification) with the germinate performance. The models

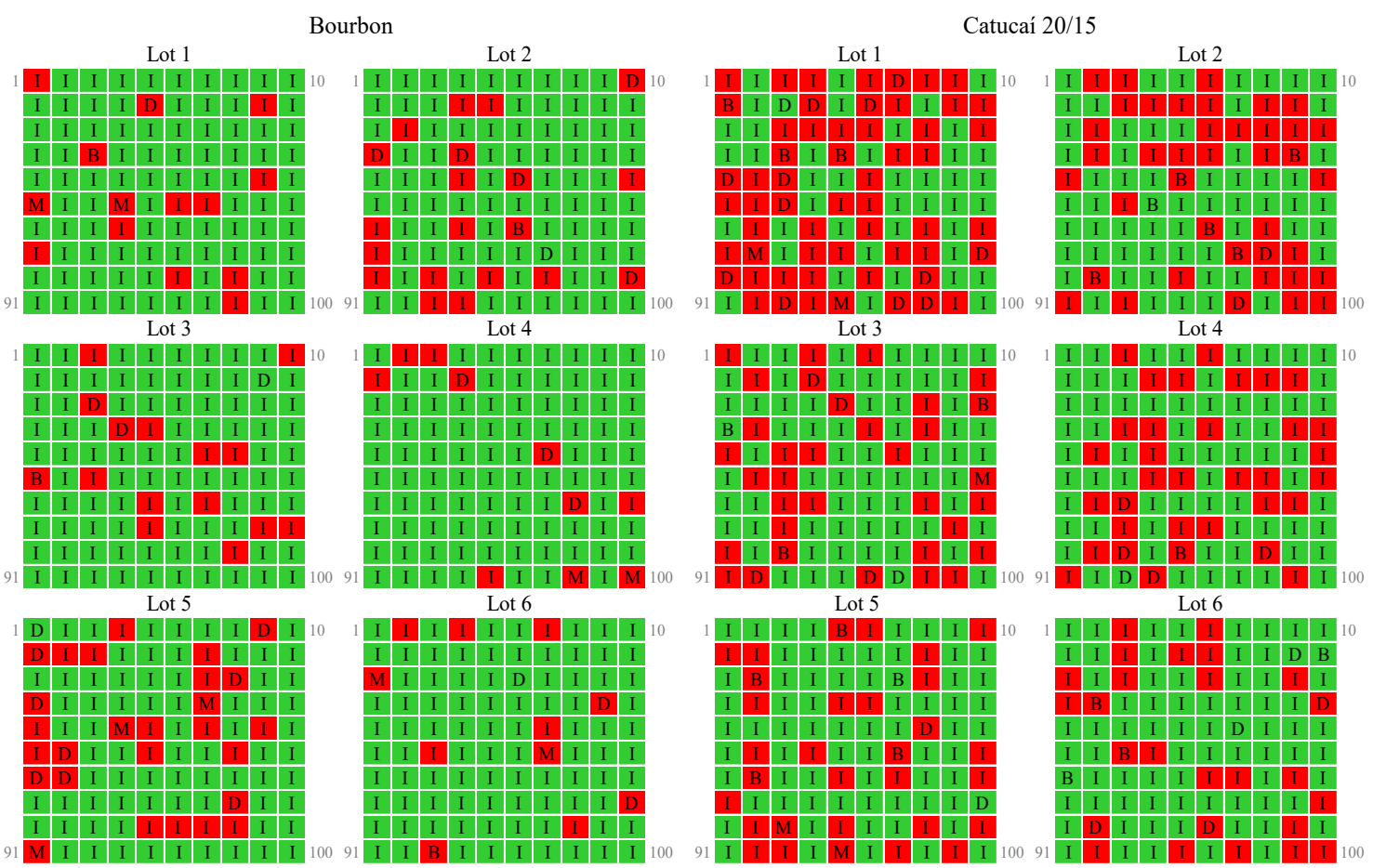

Figure 2. Relationship between intact seed (I), malformed seed (M), seed with deteriorated tissues (D) and seed with injuries caused by the coffee borer (B) identified by radiographic analysis with normal seedling (green) or seeds not germinated (red), in six seed lots of the cultivars Bourbon and Catucaí 20/15.

Table 1. Estimation of probabilities in the occurrence of intact, malformed seeds with deteriorated tissues and seeds attacked by the coffee borer in each lot of cultivars Bourbon and Catucaí 20/15 evaluated by radiographic analysis.

\begin{tabular}{ccccccc}
\hline & Cultivar & Lot & Intact & Malformed & Deteriorated & Coffee borer \\
\hline $\mathrm{a}$ & Bourbon & 1 & 0.9156 & 0.0122 & 0.0496 & 0.0224 \\
$\mathrm{~b}$ & Catucaí 20/15 & 1 & 0.8671 & 0.0183 & 0.0776 & 0.0368 \\
\hline $\mathrm{a}$ & Bourbon & 2 & 0.9407 & 0.0087 & 0.0349 & 0.0154 \\
$\mathrm{~b}$ & Catucaí 20/15 & 2 & 0.9052 & 0.0135 & 0.0556 & 0.0254 \\
\hline $\mathrm{a}$ & Bourbon & 3 & 0.9498 & 0.0074 & 0.0296 & 0.0130 \\
$\mathrm{~b}$ & Catucaí 20/15 & 3 & 0.9193 & 0.0117 & 0.0475 & 0.0214 \\
\hline $\mathrm{a}$ & Bourbon & 4 & 0.9582 & 0.0062 & 0.0246 & 0.0107 \\
$\mathrm{~b}$ & Catucaí 20/15 & 4 & 0.9324 & 0.0099 & 0.0398 & 0.0177 \\
\hline $\mathrm{a}$ & Bourbon & 5 & 0.9188 & 0.0117 & 0.0477 & 0.0215 \\
$\mathrm{~b}$ & Catucaí 20/15 & 5 & 0.8719 & 0.0177 & 0.0748 & 0.0353 \\
\hline $\mathrm{a}$ & Bourbon & 6 & 0.9418 & 0.0086 & 0.0343 & 0.0151 \\
$\mathrm{~b}$ & Catucaí 20/15 & 6 & 0.9068 & 0.0133 & 0.0547 & 0.0250 \\
\hline
\end{tabular}

Lots followed by the same letter do not differ in relation to the estimated proportions of each one of the classifications by the Tukey's test at $5 \%$ of probability. There was no effect of cultivar $\times$ lot interaction $(p=0.1301)$, and there was no lot effect $(p=0.2841)$. 
were adjusted sequentially and the effects evaluated. The effect of triple interaction was not significant $(\mathrm{p}=0.3538)$. The effect of double interaction between cultivar and lot was only marginally significant $(p=0.0557)$, but the effect of interaction between cultivars and classification was verified $(p=0.0079)$. By means of the selected model, the probabilities of germination were estimated. The highest probabilities of germination correspond to intact seeds, with a higher germinate performance for the cultivar Bourbon in relation to cultivar Catucaí 20/15, in all lots. However, the probability of intact seeds that gave rise to normal seedlings was variable between lots. When the radiographic classification corresponded to the deteriorated seed, the model showed a greater probability of germination in the Catucai 20/15 cultivar, but below 0.30 for all lots. Seeds classified as malformed presented null probabilities of germinating in both cultivars, while seeds with injuries caused by the coffee borer present non-null probabilities of germinating only for the cultivar Catucaí 20/15 in all lots, as shown in Figure 3. These relations allowed to verify the physical character of the $\mathrm{X}$-ray test, being that this one allows analyzing morphological attributes of the seed, without identifying problems related to its physiological state. Regarding the number of intact seeds that did not germinate and according to Van der Burg et al. (1994), some seeds that present themselves without problems in the X-ray test may have problems in germination, possibly due to infections by non-perceptible microorganisms in the images or because they are physiologically dead.

Examples of seeds with deteriorated tissues and injuries caused by the coffee borer of Catucai 20/15 which gave rise to normal seedlings in the germination test of seedlings are presented in Figures $1 \mathrm{~J}$ and $1 \mathrm{~K}$. However, two factors are fundamental for the correct interpretation of the images and the proper establishment of the relationship between the

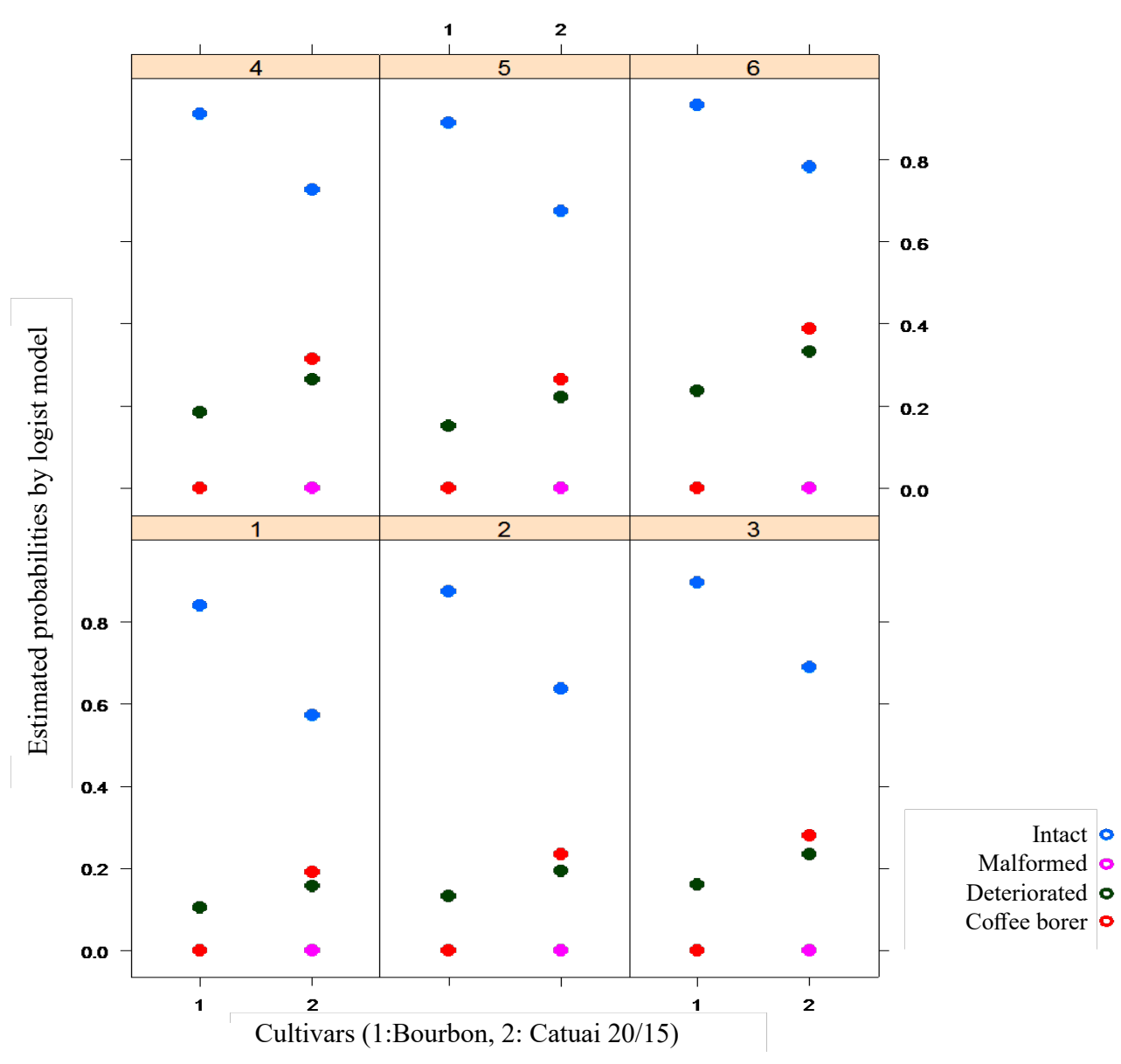

Figure 3. Representative diagram of the relationship between intact seed, malformed seed, deteriorated seed and seed with injuries caused by coffee borer identified by radiographic analysis and relation to germination and emergence of seedlings in six seed lots of the cultivars Bourbon and Catucaí 20/15. Quantile-Quantile chart with simulated envelopes at $95 \%$ confidence. 
occurrence of internal injuries and the germinate performance; the first consists in the knowledge of the X-ray test principle and the second in the knowledge of the internal morphology of the seed being analyzed. In this research, the formation of normal seedlings from seeds with occurrence of damaged tissues and with injuries caused by the coffee borer can be directly attributed to the location of these injuries. Analyzing the radiographic images of the seeds of Figure $1 \mathrm{~J}$ and $1 \mathrm{~K}$ it is possible to verify that the injuries occurred in the endosperm of the seeds and in a position opposite to the region of the embryonic axis not visualised in radiography (arrow in Figure $1 \mathrm{~J}$ and circle in Figure 1K). Therefore, the determining factor for determining negative effects on germination is whether the injury is occurring or not in a vital region of the seed, such as the embryonic axis. Results obtained by Pinto et al. (2007) verified that the moisture damages classified as non-severe in the axis and cotyledons region did not interfere in the germination of soybean seeds. In the same line, data reported by Forti et al. (2008) on bean seeds indicated that most of the seeds without mechanical damage and without stink bug damage originated normal seedlings; however, these same authors observed that mechanical damages classified as severe in the embryonic axis and in the cotyledons had a close relation with the generation of abnormal seedlings.

Regarding damages due to deterioration, the seed treatment system is an aspect that should be considered in the evaluation of the physiological potential of coffee seeds, since seeds that are submitted to mechanical pulping are more susceptible to deterioration, which can affect germination (Giomo et al., 2008). In a study by Marchi et al. (2011), damage caused by the deterioration of the tissues in peanut seeds appeared as dark spots in the radiographic images and when they occurred in some regions of the cotyledons affected the germination. Pinto et al. (2009) using the X-ray test, identified internal damage in jatropha seeds, where they found a high relation between seeds with severe damage and the percentages of seedlings and dead seeds.

Although visualization of the embryonic axis by radiographic analysis was not possible due to the same tissue density, the radiographic images allowed to observe the main internal changes of the seeds. Therefore, the efficiency of the radiographic analysis in the identification of malformed seeds, with deteriorated tissues and with injuries caused by the coffee borer, must be considered for both cultivars. Despite variations in the occurrence of these injuries among the cultivars, the radiographic analysis made it possible to identify their location accurately of these alterations, which allowed establishing association with the performance of coffee seeds.

Regarding the emergence of seedlings in Bourbon, the percentage of seedlings emerged at the end of the test varied between 74 and $90 \%$. The best performances were observed for lots 4 and 6 , statistically differing from lot 5 which also presented the lowest seedling emergence rate index as shown in Table 2. For Catucaí 20/15, the seedling emergence

Table 2. Shoot length, stem diameter, dry matter mass of the shoot, seedling emergence speed index (IVE) and seedling emergence of the cultivars Bourbon and Catucaí 20/15.

\begin{tabular}{|c|c|c|c|c|c|c|}
\hline \multirow{2}{*}{ Cultivar } & \multirow{2}{*}{ Lot } & Shoot length & Stem diameter & Dry matter & \multirow{2}{*}{ Emergence (\%) } & \multirow{2}{*}{ IVE } \\
\hline & & $(\mathrm{cm})$ & $(\mathrm{mm})$ & (mg) & & \\
\hline \multirow{6}{*}{ Bourbon } & 1 & $5.86 \mathrm{~b}$ & $1.86 \mathrm{ab}$ & $89.93 \mathrm{ab}$ & $86 \mathrm{ab}$ & $1.432 \mathrm{a}$ \\
\hline & 2 & $5.82 \mathrm{~b}$ & $1.87 \mathrm{~b}$ & $108.42 \mathrm{a}$ & $80 \mathrm{ab}$ & $1.257 \mathrm{ab}$ \\
\hline & 3 & $5.72 \mathrm{~b}$ & $1.93 \mathrm{ab}$ & $102.78 \mathrm{ab}$ & $85 \mathrm{ab}$ & $1.359 \mathrm{a}$ \\
\hline & 4 & $6.41 \mathrm{a}$ & $1.96 \mathrm{a}$ & $108.59 \mathrm{a}$ & $90 \mathrm{a}$ & $1.397 \mathrm{a}$ \\
\hline & 5 & $5.92 \mathrm{~b}$ & $1.95 \mathrm{ab}$ & $95.66 \mathrm{ab}$ & $74 \mathrm{~b}$ & $1.103 \mathrm{~b}$ \\
\hline & 6 & $6.42 \mathrm{a}$ & $1.95 \mathrm{a}$ & $80.62 \mathrm{~b}$ & $89 \mathrm{a}$ & $1.370 \mathrm{a}$ \\
\hline CV (\%) & & 16.2 & 9.41 & 57.22 & 7.19 & 15.97 \\
\hline \multirow{6}{*}{ Catucaí 20/15 } & 1 & $3.71 \mathrm{~b}$ & $1.78 \mathrm{ab}$ & $79.32 \mathrm{~b}$ & $44 \mathrm{c}$ & $0.810 \mathrm{~b}$ \\
\hline & 2 & $3.8 \mathrm{~b}$ & $1.77 \mathrm{~b}$ & $78.94 \mathrm{~b}$ & $62 \mathrm{~b}$ & $1.137 \mathrm{ab}$ \\
\hline & 3 & $3.85 \mathrm{ab}$ & $1.79 \mathrm{ab}$ & $83.21 \mathrm{ab}$ & $66 \mathrm{ab}$ & $1.153 \mathrm{ab}$ \\
\hline & 4 & $3.79 \mathrm{~b}$ & $1.78 \mathrm{a}$ & $79.81 \mathrm{~b}$ & $67 \mathrm{ab}$ & $1.228 \mathrm{ab}$ \\
\hline & 5 & $4.01 \mathrm{ab}$ & $1.79 \mathrm{ab}$ & $88.49 \mathrm{ab}$ & $69 \mathrm{ab}$ & $1.318 \mathrm{a}$ \\
\hline & 6 & $4.2 \mathrm{a}$ & $1.81 \mathrm{a}$ & $107.7 \mathrm{a}$ & $74 \mathrm{a}$ & $1.424 \mathrm{a}$ \\
\hline CV (\%) & & 13.26 & 8.54 & 57.8 & 15.07 & 16.13 \\
\hline
\end{tabular}

Lots followed by the same letter do not differ in relation to the estimated proportions of each one of the classifications by the test Tukey's at $5 \%$ of probability. 
percentage ranged from 44 to $74 \%$. The best performance was observed in lot 6 by the emergence percentage and together with lot 5 by the seedling emergence speed index, presented in Table 2. It is important to emphasize that all seed lots were subjected to the same environmental conditions during the seedling emergence test period; the temperatures ranged from 23 to $28{ }^{\circ} \mathrm{C}$ and the relative humidity of the air was between 67 and $78 \%$. Therefore, the seedling emergence test made it possible to safely identify differences in physiological potential between seed lots in both cultivars.

Regarding the variables of seedling performance, it was observed higher values in the lots of the cultivar Bourbon in comparison with those of the cultivar Catucaí 20/15. It was verified that there were significant effects of cultivar and lot, as well as the interaction between them for the parameters of shoot length and dry matter mass of the shoot $(p<0.05)$. As the interaction was significant, the comparison of averages of the lots within each cultivar (Tukey's test) was done, as shown in Table 2. For the diameter of the stem, higher values were also observed in the lots of the Bourbon; however, the variability between the cultivars was similar, it was verified that there was no effect of the interaction between cultivar and lot $(\mathrm{p}=0.080)$ at the level of significance of $5 \%$. As the interaction was not significant, we present the comparison of means of the main factors, presented in Table 2. In studies on the performance of coffee plants of the cultivar Catucai AM 2SL, Araujo et al. (2016) observed higher values for stem diameter $(1.93 \mathrm{~mm})$ and seedling height $(5.3 \mathrm{~cm})$ at 150 days of age. These results may have been influenced by factors such as the greater age of the seedlings, the substrate (soil: manure and nutrients) and the containers used (polyethylene bags). The environmental conditions were not reported in the research.

As it can be seen in Table 1, in the cultivar Bourbon lot 5 , which presented the lowest proportion of intact seeds, it was also due to the lower shoot length. Similar relationships were observed in lot 1 , which also had the smallest diameter of the stem as shown in Table 2. These results agree with other studies carried out on different species such as maize (Cicero and Banzatto-Junior, 2003), which showed the relationship between mechanical damage and losses in the physiological performance of seeds. Forti et al. (2008) made the same observation with mechanical damages and those caused by stink bugs in bean seeds. Similarly, Carvalho et al. (2009) identified internal damages due to deterioration in pumpkin seeds that negatively affected the physiological potential.

As for the cultivar Bourbon, the comparative analysis of the radiographic images of the seeds with the cultivar Catucaí 20/15 and the performance of the seedlings showed a relationship between failure in germination and emergence of seedlings and occurrence of malformed seeds, seeds with damaged tissues and seeds with injury caused by the coffee borer. Similar relationships also occurred for the shoot length, stem diameter and seedling dry matter mass, as shown in Table 2. The results of seedling evaluations indicate that the variation in the size of the seeds of Catucaí 20/15, verified in the X-ray test (Figure 1A), was also a determinant factor in the generation of low quality seedlings in relation to the physiological variables of development (shoot length, stem diameter and dry matter mass). The seeds of coffee of larger size or greater density generate seedlings of superior quality than seeds of smaller size or lower density, determined by the growth (Favarin et al., 2003; Giomo et al., 2004). This evidences the importance of the selection of seeds from physical characteristics, aiming at the obtaining of more homogeneous initial stands.

In this research, the radiographic analysis represented an efficient method for the evaluation of the internal morphology of coffee seeds and the identification of physical changes that may be associated with loss of germination. Although it is a procedure that does not evaluate the physiological and metabolic conditions of seeds, the X-ray analysis allows establishing relations with the physiological potential, because the low doses of radiation required for seed analysis (energies of approximately 0.12 to $12 \mathrm{keV}$ ) do not cause changes in the atomic constitution of the tissues. Thus, the use of radiographic analysis to evaluate the internal morphology of coffee seeds may help to select the best seeds to ensure efficiency in the seedling production process.

\section{Conclusions}

The analysis of radiographic images is efficient in identifying the main changes in the internal morphology of the coffee seeds, allowing to relate their occurrence to the germinate performance of the seed lots.

\section{References}

AGRESTI, A. Categorical Data Analysis. $3^{\text {rd }}$ edition, Wiley, 2012.

AGUIAR, A.T.E.; GUERREIRO-FILHO, O.; MALUF, M.P.; GALLO, P.B.; FAZUOLI, L.C. Caracterização de cultivares de Coffea arabica mediante utilização de descritores mínimos. Bragantia, v.63, n.2, p.179-192, 2004. http://dx.doi.org/10.1590/ S0006-87052004000200003

ARAUJO, A.; ARAUJO, E.; ABUD, H.; ARAUJO, I. Utilizacão da técnica secafé em sementes de diferentes cultivares. Coffe Science, v.11, n.3, p.386-394, 2016. http://dx.doi.org/10.25186/cs.v11i3.1109 
ASCANİ, E.C.E. Biología del café. Caracas: Universidad Central de Venezuela, 1994. 308p.

BINO, R.J.; AARTSE, J.W.; Van der BURG, W.J. Non-destructive X-ray of Arabidopsis embryo mutants. Seed Science Research, v.3, n.3, p.167-170, 1993. https://doi.org/10.1017/S0960258500001744

CARVALHO, L.R.; CARVALHO, M.L.M.; DAVIDE, A.C. Utilização do teste de raios $\mathrm{X}$ na avaliação da qualidade de sementes de espécies florestais de Lauraceae. Revista Brasileira de Sementes, v.31, n.4, p.57-66, 2009. https://doi.org/10.1590/S010131222009000400007

CICERO, S.M.; BANZATTO-JUNIOR, H.L. Avaliação do relacionamento entre danos mecânicos e vigor, em sementes de milho, por meio da análise de imagens. Revista Brasileira de Sementes, v.25, n.1, p.29-36, 2003. http://dx.doi.org/10.1590/S010131222003000100006

CLAY, J. Coffee. In: World Agriculture and the Environment. Washington, DC: Island Press, 2004. p.69-91.

DAMON, A. Review of the biology and control of the coffee berry borer, Hypothenemus hampei (Coleoptera: Scolytidae). Bulletin of Entomological Research, v.90, n.6, p.453-465, 2000. https://doi. org/10.1017/S0007485300000584

Dell'AQUILA, A. Pepper seed germination assessed by combined $\mathrm{X}$-radiography and computer-aided imaging analyses. Biologia Plantarum, v.51, n.4, p.777-781, 2007. https://doi.org/10.1007/ s10535-007-0159-9

EIRA, M.T.S.; SILVA, E.A.A.; CASTRO, R.D.; DUSSERT, S.; WALTERS, C.; BEWLEY, J.D.; HILHORST, H.W.M. Coffee seed physiology. Brazilian Journal of Plant Physiology, v.18, n.1, p.149163, 2006. http://dx.doi.org/10.1590/S1677-04202006000100011

FAVARIN, J.L.; COSTA, J.D.; NOVEMBRE, A.D.C.; FAZUOLI, L.C.; FAVARIN, M.G.G.V. Características da semente em relação ao seu potencial fisiológico e a qualidade de mudas de café (Coffea arabica L.). Revista Brasileira de Sementes, v.25, n.2, p.13-19, 2003. http://dx.doi.org/10.1590/S0101-31222003000400003

FORTI, V.A.; CICERO, S.M.; PINTO, T.L.F. Análise de imagens na avaliação de danos mecânicos e causados por percevejos em semente de feijão. Revista Brasileira de Sementes, v.30, n.1, p.121-130, 2008. http://dx.doi.org/10.1590/S0101-31222008000100016

GIOMO, G.S.; NAKAGAWA, J.E.; GALLO, P.B. Beneficiamento de sementes de café e efeitos na qualidade física. Bragantia, v.67, n.4, p.997-1010, 2008. http://dx.doi.org/10.1590/S000687052008000400024

GIOMO, G.S.; RAZERA, L.F.; GALLO, P.B. Beneficiamento e qualidade de sementes de café arábica. Bragantia, v.63, n.2, p.291297, 2004. http://dx.doi.org/10.1590/S0006-87052004000200014

GOMES-JUNIOR, F.G. Aplicação da análise de imagens para avaliação da morfologia interna de sementes. Informativo ABRATES, v.20. p.33-39, 2010.
GOULART, P.F.P.; ALVES, J.D.; CASTRO, E.M.; FRIES, D.D.; MAGALHÃES, M.M.; MELO, H.C. Aspectos histoquímicos e morfológicos de grãos de café de diferentes qualidades. Ciência Rural, v.37, n.3, p.662-666, 2007. http://dx.doi.org/10.1590/S010384782007000300010

ISTA. International Seed Testing Association. International rules for testing seed. Seed Science and Technology, v.13, n.2, p.300-500, 1995.

MAGUIRE, J.D. Speed of germination-aid in selection and evaluation for seedling emergence and vigor. Crop Science, v.2, n.1, p.176-177, 1962.

MARCHI, J.L.D.; CICERO, S.M.; GOMES-JUNIOR, F.G. Utilização da análise computadorizada de plântulas na avaliação do potencial fisiológico de sementes de amendoim tratadas com fungicida e inseticida. Revista Brasileira de Sementes, v.33, n.4, p.652-662, 2011. http://dx.doi.org/10.1590/S0101-31222011000400007

MCCULLAGH, P. Regression methods for ordinal data. Journal of the Royal Statistical Society, v.42, p.109-142, 1980.

MENDES, A.J.T.; BACCHI, O. Os grãos mocas de café. Revista do Instituto do Café, v.27, n.161, p.996-999, 1940.

PINTO, T.L.F.; CICERO, S.M.; FORTI, V.A. Avaliação de danos por umidade em sementes de soja utilizando a técnica da análise de imagens. Revista Brasileira de Sementes, v.29, n.3, p.31-38, 2007. http://dx.doi.org/10.1590/S0101-31222007000300004

PINTO, T.L.F.; MARCOS-FILHO, J.; FORTI, V.A.; CARVALHO, C.; GOMES-JUNIOR, F.G. Avaliação da viabilidade de sementes de pinhão manso pelos testes de tetrazólio e de raios X. Revista Brasileira de Sementes, v.31, n.2, p.195-201, 2009. http://dx.doi. org/10.1590/S0101-31222009000200023

R CORE TEAM. R: a language and environment for statistical computing. $R$ Foundation for Statistical Computing, Vienna, Austria. 2018.

ROSA, S.D.V.F.; BRANDÃO-JÚNIOR, D.S.; VON PINHO, E.V.R.; VEIGA, A.D.; SILVA, L.H.C. Effects of different drying rates on the physiological quality of Coffea canephora Pierre seeds. Brazilian Journal of Plant Physiology, v.17, n.2, p.199-205, 2005. http:// dx.doi.org/10.1590/S1677-04202005000200002

SANTOS, A.S.; SILVA, R.F.; PEREIRA, M.G.; MACHADO, J.C. $\mathrm{X}$-ray technique application in evaluating the quality of papaya seeds. Seed Science and Technology, v.37, n.3, p.776-780, 2009. https://doi.org/10.15258/sst.2009.37.3.25

SGUAREZI, C.N.; BRACCINI, A.L.; SCAPIM, C.A.; BRACCINI, M.C.L.; DALPASQUALE, V.A. Avaliação de tratamentos prégerminativos para melhorar o desempenho de sementes de café (Coffea arábica L.). II. Processo de umidificação. Revista Brasileira de Sementes, v.23, n.2, p.162-170, 2001. http://dx.doi. org/10.17801/0101-3122/rbs.v23n2p162-170

SILVA, M.C.; NICOLE, M.; RIJO, L.; GEIGER, J.P.; RODRIGUESJUNIOR, C.J. Cytochemical aspects of the plant-rust fungus interface during the compatible interaction Coffea arabica (cv. Caturra)-Hemileia vastatrix (race III). International Journal of Plant Sciences, v.160, n.1, p.79-91, 1999. https://doi.org/10.1086/314113 
SILVA, V.N.; CICERO, S.M.; BENNETT, M. Relationship between eggplant seed morphology and germination. Revista Brasileira de Sementes, v.34, n.4, p.597-604, 2012. http://dx.doi.org/10.1590/ S0101-31222012000400010
VAN DER BURG, W.J.; AARTSE, J.W.; VAN ZWOL, R.A.; JALINK, H.; BINO, R.J. Predicting tomato seedling morphology by X-ray analysis of seeds. Journal of the American Society of Horticultural Sciences, v.119, n.2, p.258-263, 1994. https://doi. org/10.21273/JASHS.119.2.258 